\title{
Effect of baru (Dipteryx alata Vog.) addition on the composition and nutritional quality of cookies
}

\author{
Kelly Aparecida CAETANO ${ }^{1 \star}$, Juliana Muselli CEOTTO${ }^{1}$, Ana Paula Badan RIBEIRO ${ }^{2}$, \\ Francielli Pires Ribeiro de MORAIS², Roseli Aparecida FERRARI ${ }^{3}$, Maria Teresa Bertoldo PACHECO ${ }^{3}$, \\ Caroline Dario CAPITANI ${ }^{1}$
}

\begin{abstract}
The use of the defatted baru almond (Dipteryx alata Vog.) prevents the production of waste residues after extraction of its oil (partially defatted baru flour), representing a process of interest from an environmental point of view. The aim of this study was to prepare oat cookies with functional properties, replacing $100 \%$ soy oil for baru oil and $30 \%$ wheat flour for partially defatted baru flour (baru cookie). Baru cookies presented a higher moisture (7.80\%), probably due to the high content of dietary

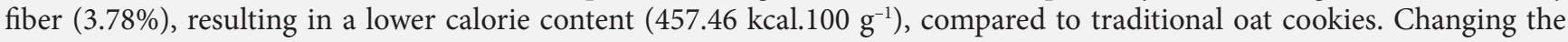
formulation resulted in the enrichment of a number of microelements, including phosphorus $\left(\sim 197.90 \mathrm{mg}^{\left.100 \mathrm{~g}^{-1}\right)}\right.$ and iron $\left(\sim 21.56 \mathrm{mg} .100 \mathrm{~g} \mathrm{~g}^{-1}\right)$. Baru oil increased the concentration of unsaturated fatty acids $(\sim 76.11 \%)$, consisting of approximately $50.37 \%$ monounsaturated (MUFA), and $25.74 \%$ polyunsaturated fatty acids (PUFA). The total phenolic compound content was approximately doubled in the baru cookie. As such, the baru cookie presents an interesting composition from a nutritional point of view, having a high protein and dietary fiber content, in addition to presenting substantial concentrations of iron and oleic acid, and may be used as part of a healthy diet.
\end{abstract}

Keywords: baru; unsaturated fatty acids; whole utilization of foods; food composition; dietary fibers.

Practical Application: The use of baru in cookies increases their protein content, iron and monounsaturated fatty acids, such as oleic acid.

\section{Introduction}

The baru almond (Dipteryx alata Vog.) is an edible seed from the fruit of the "barueiro" tree, which is native to the Cerrado biome. The barueiro fruit is of the drupe type and, therefore, has a fibrous pulp with a hardened center containing a single edible oleaginous seed (Lorenzi, 2002). The tree is native to the Brazilian Cerrado, belongs to the Leguminosae family, and has an average height of 15 meters. It flowers from October to January and its fruits ripen between March and August, producing on average of 2000-6000 fruits per plant (Pio Corrêa, 1984; Sano et al., 2006).

The tree's seed or baru almond contains approximately $38.20 \%$ lipids, consisting predominantly of unsaturated fatty acids; $23.90 \%$ protein; $15.80 \%$ carbohydrates; $13.40 \%$ dietary fiber, of which $2.50 \%$ are soluble fibers and $10.90 \%$ are insoluble fibers (Pineli et al., 2015a). The baru almond also has a high mineral content, especially of calcium, iron, magnesium, potassium, phosphorus and zinc (Sousa et al., 2011; Siqueira et al., 2012; Takemoto et al., 2001).

Soybean oil is the most widely-consumed vegetable oil in Brazil, mainly due to its cost; however, the demand for vegetable oils with differentiated chemical compositions is currently increasing (Pedreiro, 2007; Santos et al., 2013). Some oils, such as baru oil, stand out due to their high contents of $\alpha$-tocopherol
(5 mg / $100 \mathrm{~g}$ ) and peanut oil-like fatty acid composition (50.40\% oleic acid and $28.0 \%$ linoleic acid) (Takemoto et al., 2001; Santos et al., 2013).

The inclusion of $20 \mathrm{~g}$ baru almond in the diet of subjects with mild hypercholesterolemia (Bento et al., 2014) significantly reduced serum total cholesterol (TC), low-density lipoprotein (LDL-c) and non-high-density lipoprotein (non-HDL-c) (Bento et al., 2014). Animals fed for two months with a high-fat diet and 15\% baru almond lipids showed a reduction in lipid peroxidation and an improvement in serum lipids (Fernandes, 2011). Additionally, Siqueira et al. (2012) reported that the feeding of iron-supplemented rats on diets with $10 \%$ baru almond for 17 days protected them against tissue damage and lipid oxidation caused by iron-induced oxidative stress (Siqueira et al., 2012).

Due to its nutritional composition and promising study results, the baru almond has been amply explored, particularly with a view to developing foods with added baru almond and/or its by-products (Soares et al., 2007; Rocha \& Cardoso Santiago, 2009; Santos et al., 2012; Pineli et al., 2015a, b). It has been shown that cookies developed with different partially defatted baru flour (PDBF) concentrations in substitution of wheat flour (WF) and cassava starch (CS) (Soares et al., 2007) present 
increases in protein, lipids, iron, calcium and fiber, as well as improved nutritional quality. The addition of $8.0 \% \mathrm{PDBF}$ to the cookie does not affect the sensory preferences of consumers (Soares et al., 2007).

As such, the use of baru derivatives in different types of food can contribute to the utilization of alternative regional products, contributing to the conservation and sustainable development of native Cerrado (Soares et al., 2007; Pineli et al., 2015a). Furthermore, use of the whole baru almond, employing baru almond oil and PDBF in cookies, presents an interesting alternative from an economic and nutritional point of view.

\section{Material and methods}

\subsection{Obtaining the sample (baru almonds)}

Baru almonds were obtained from the municipal market of Goiânia (GO, Brazil) and originated from the Cerrado of the Midwest region. Other ingredients used for making cookies were of known brands and acquired in local shops (SP, Brazil).

\subsection{Baru oil extraction}

The extraction of baru almonds oil was carried out using a cold press type expeller, with processing of 40 to $60 \mathrm{~kg} / \mathrm{h}$ raw material, at the Institute of Food Technology (ITAL), in Campinas (SP, Brazil). To improve the baru oil extraction performance, baru almonds were initially subjected to mechanical disintegration without heating (coarse grinding) to break the original almond structure (which is wrapped by epicarp) to facilitate the release of the oil. The almonds were placed in the expeller for pressing; the duration of each batch pressing was 10 minutes on average. The crude oil yield was calculated by the ratio of the mass of oil obtained in the press to the initial mass of oil in the grain. The partially deffated baru flour yield was calculated using the ratio of the mass of partially deffated baru flour obtained from the pressing to the initial grain mass.

After the extraction process, the baru oil was obtained, as well as partially deffated baru flour (PDBF) as a by-product. The oil obtained was stored in an amber bottle at $-20^{\circ} \mathrm{C}$ for later use, and the PDBF was subjected to the autoclaving process for inhibiting antinutritional factors.

\subsection{Inactivation of the trypsin inhibitor}

The PDBF obtained after oil extraction was autoclaved to inactive antinutritional factors, using the following conditions: $120{ }^{\circ} \mathrm{C}$ for 20 minutes under a pressure of $1 \mathrm{kgf} / \mathrm{m}^{2}$, according to Siqueira et al. (2015).

\subsection{Cookie development}

Initially, pilot tests were carried out in order to produce cookies with interesting nutritional properties and pleasant sensory aspects. Therefore, the original soy oil formulation was totally replaced by baru oil and PDBF partially replaced (30\%) the wheat flour (WF) of the original formulation. The percentage of substitution by PDBF was defined after preliminary tastings. The following percentages of WF replacement by PDBF were initially used during the development of the cookies; $15 \%, 30 \%$ and $45 \%$. After defining the best concentrations of ingredients, the formulation described in Table 1 was obtained.

\subsection{Baru oil fatty acid profile}

The fatty acid profile of baru oil was analyzed on a capillary gas chromatograph (Agilent, 6850 Series GC System, U.S.A.) after esterification, Hartman \& Lago (1973). The methyl esters of fatty acids were separated according to the method of American Oil Chemists' Society (2009) using an Agilent DB-23 capillary column (50\% cyanopropyl-methylpolysiloxane), with dimensions $60 \mathrm{~m}, \varnothing$ int: $0.25 \mathrm{~mm}, 0.25 \mu \mathrm{m}$ film. The operating conditions of the chromatograph were as follows: column flow $1.00 \mathrm{~mL} / \mathrm{min}$; linear velocity $24 \mathrm{~cm} / \mathrm{sec}$; detector temperature $280^{\circ} \mathrm{C}$; injector temperature $250{ }^{\circ} \mathrm{C}$; furnace temperature $110{ }^{\circ} \mathrm{C}$; C-5 min $110-215^{\circ} \mathrm{C}\left(5^{\circ} \mathrm{C} / \mathrm{min}\right), 215^{\circ} \mathrm{C}-24 \mathrm{~min}$. The carrier gas used was helium, and an aliquot of $1 \mu \mathrm{L}$ of the samples was injected into the apparatus. Fatty acid determination was determined by comparing the peak retention times with the respective fatty acid standards.

\subsection{Extract preparation}

To obtain the extracts for cookies, $1.0 \mathrm{~g}$ of dry material was added to deionizated water, agitating in a vortex, applying ultrasound and centrifuging at $11000 \mathrm{rpm} / 15 \mathrm{~min}$ at $4 \pm 1{ }^{\circ} \mathrm{C}$ (5810-R, Germany) and the extract was filtered with filter paper (Whatmann $\mathrm{n}^{\circ} 3$ ). Subsequently, $80 \%$ ethanol was added to the filtrate and agitated in a vortex, before applying ultrasound and centrifuging (sequence repeated twice) at $11000 \mathrm{rpm} / 15 \mathrm{~min}$ at $4 \pm 1^{\circ} \mathrm{C}(5810-\mathrm{R}$, Germany) and filtered with filter paper (Whatmann $\mathrm{n}^{\circ} 3$ ). The extract was transferred to a volumetric flask and the contents adjusted with $80 \%$ ethanol to a volume of $20 \mathrm{~mL}$. Subsequently the extracts were packaged in amber bottles and kept at $-80^{\circ} \mathrm{C}$ until the time of determination of total phenolic compound concentrations.

\subsection{Determination of total phenolic concentration}

The Folin-Ciocalteu method was used to quantify the concentration of total phenolic compounds (FT) of the oat cookie and baru cookie extracts, according to the methodology described by Singleton \& Rossi (1965). Initially a standard curve was elaborated

Table 1. Percentage compositions of ingredients in the baru cookie and oat cookie formulations.

\begin{tabular}{lcc}
\hline \multicolumn{1}{c}{ Ingredients (\%) } & Baru cookie & Oat cookie \\
\hline Oat & 28.4 & 28.4 \\
Brown sugar & 18.1 & 18.1 \\
Wheat flour (WF) & 17.5 & 25.0 \\
Partially deffated baru flour (PDBF) & 7.5 & -- \\
Egg & 14.0 & 14.0 \\
Soy oil & -- & $\mathbf{1 2 . 5}$ \\
Baru oil & $\mathbf{1 2 . 5}$ & -- \\
Vanilla extract & 1.3 & 1.3 \\
Baking poder & 0.7 & 0.7 \\
Total yield (g) & 100.0 & 100.0 \\
\hline
\end{tabular}


using solutions with increasing concentrations $(50-300 \mu \mathrm{g} / \mathrm{mL})$ of gallic acid, subsequently, $100 \mu \mathrm{L}$ of Folin-Ciocalteu reagent were added to $20 \mu \mathrm{L}$ of each extract in a microplate. The mixture was allowed to react at room temperature $\left(25 \pm 1^{\circ} \mathrm{C}\right)$ in the dark for 5 minutes. Sodium carbonate $\left(\mathrm{Na}_{2} \mathrm{CO}_{3} ; 80 \mu \mathrm{L}\right)$ was then added at $7.5 \%$, before incubating for 30 minutes in a dark room and at room temperature $\left(25 \pm 1{ }^{\circ} \mathrm{C}\right)$. The absorbance was measured at $750 \mathrm{~nm}$ using a microplate reader (Microplate Spectrophotometer, Biotek, Winooski). Results are expressed as $\mathrm{mg}$ of gallic acid equivalents (EAG) per 100 grams of the dry sample.

\subsection{Chemical composition}

The PDBF, baru almond and baru cookie were analyzed to determine their nutritional compositions (macronutrients and minerals). Their moisture, protein and ash concentrations were determined using the methods described by the Association of Official Analytical Chemists (American Oil Chemists' Society, 2009). The protein content was determined by the micro-Kjeldahl method, multiplying the total nitrogen by a factor of 6.25 . The dosage of the lipid content was performed using the Soxhlet method, employing ethyl ether. The carbohydrate content was calculated by the difference. The dietary fiber content was determined by the enzymatic-gravimetric method of Prosky et al. (1988). The whole metabolizable energy value was expressed in kilocalories ( $\mathrm{kcal}$ ), considering the Atwater conversion factors: $(4 \mathrm{x}$ g protein $)+(4 \mathrm{x}$ g carbohydrates (carbohydrates total dietary fiber $)+(9 \times \mathrm{g}$ lipids total). In addition, the mineral composition was determined by elemental Scanning Electron Microscopy (SEM) microanalysis (Hitachi brand, model TM 3000 - Tabletop Microscope) coupled with Dispersive Energy Spectroscopy (DES) (Hitachi brand, Swift model ED3000). The samples were sectioned into small pieces and placed on the equipment's platform. Minerals were analyzed with magnifications of 2500, 5000 and 8000 times (Goldestein \& Newbury, 1992). All data were converted to dry base parameters.

\section{Results}

\subsection{Oil extraction yield and baru oil fatty acid profile}

After cold oil extraction using a press type expeller, we obtained an oil yield of $20.43 \%$, resulting in $79.47 \%$ PDBF. Thus, each $1000 \mathrm{~g}$ baru almond yielded approximately $204.30 \mathrm{~g}$ of oil. The analysis of the fatty acid profile of the baru oil, as well percentages in relation the recommendation for a daily diet can be observed in Table 2. The consumption of a serving size of the baru cookie $(30 \mathrm{~g})$ provides, on average, $4.00 \%$ of the daily recommendation of unsaturated fatty acids.

\subsection{Total phenolic composition of cookies}

Total phenolic (TP) concentrations were $13.6 \mathrm{mg} \mathrm{GAE} / 100 \mathrm{~g}$ for the oat cookie and $25 \mathrm{mg} \mathrm{GAE} / 100 \mathrm{~g}$ for the baru cookie. The amount of TP found in the Baru cookie was almost 2 times greater than that of the oat cookies.

\subsection{Centesimal composition and phenolic compound concentration of cookies}

Before preparing the cookies, the antinutritional factors of the PDBF were inactivated by autoclaving, as recommended by Siqueira et al. (2015). Autoclaving is a thermal process that controls temperature and ambient pressure, in addition to applying moist heat, in a completely closed system to provide reproducible conditions that can improve the digestibility of food protein (Siqueira et al., 2015). In a previous study by our research group, we found similar levels of trypsin inhibitor in whole baru (12.84 $\pm 0.10 \mathrm{UTI} / \mathrm{mg})$ and PDBF $(12.67 \pm 0.15 \mathrm{UTI} / \mathrm{mg})$. After autoclaving the PDBF, the value of this antinutrient is reduced to $0.46 \pm 0.44 \mathrm{UTI} / \mathrm{mg}$ without damaging its nutritional characteristics.

The results of the centesimal composition of baru almond and PDBF are described in Table 3 . The concentrations of baru cookie nutrients are described in Chart 1 , as are the results of

Table 2. Fatty acid composition of baru almond oil, expressed as percentages (mean \pm SD) of the daily recommended value (DV) for the main fatty acids and percentage adequacy of the main fatty acids in a serving size of cookie $(30 \mathrm{~g})$.

\begin{tabular}{lccc}
\hline \multicolumn{1}{c}{ Fatty acids } & Baru almond oil (\%) & $\begin{array}{c}\text { Daily recommended value (Kcal) } \\
\text { C16:0 (palmitic) }\end{array}$ & $\begin{array}{c}\text { Percentage serving size in relation } \\
\text { to the recommended daily value } \\
\text { (\%DV) }\end{array}$ \\
\hline C18:0 (stearic) & $6.38 \pm 0.09$ & - & - \\
C20:0 (arachidonic) & $6.66 \pm 0.01$ & - & - \\
C22:0 (behenic) & $1.72 \pm 0.01$ & - & - \\
C24:0 (lignoceric) & $3.57 \pm 0.04$ & - & - \\
C18:1 (oleic) - $\omega 9$ & $5.03 \pm 0.08$ & - & - \\
C20:1(elaidic/gadoleic) & $48.26 \pm 0.04$ & - & - \\
C18:2 (linoleic) - $\omega 6$ & $2.11 \pm 0.02$ & $100-200^{\mathrm{a}}$ & 5.12 \\
C18:3 (linolenic) $-\omega 3$ & $25.59 \pm 0.03$ & $12-24^{\mathrm{b}}$ & 0.25 \\
Total SFA & $0.15 \pm 0.01$ & $<200^{\mathrm{c}}$ & 3.5 \\
Total UFA & 23.36 & $520-600^{\mathrm{a}}$ & 4.07 \\
Total MUFA & 76.11 & $400^{\mathrm{a}}$ & 3.78 \\
Total PUFA & 50.37 & $120-200^{\mathrm{a}}$ & 4.83 \\
\hline
\end{tabular}

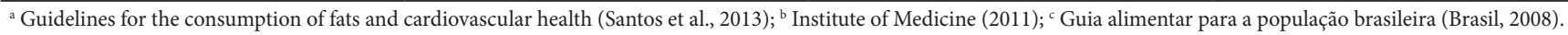


Table 3. Centesimal composition of baru almond and partially defatted baru flour (PDBF) (mean \pm SD).

\begin{tabular}{|c|c|c|}
\hline Analysis & 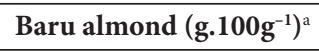 & PDBF $\left(\mathrm{g} .100 \mathrm{~g}^{-1}\right)^{\mathrm{a}}$ \\
\hline Moisture & $4.10 \pm 0.06$ & $6.53 \pm 0.02$ \\
\hline Ash & $2.65 \pm 0.01$ & $3.04 \pm 0.04$ \\
\hline Proteins & $10.87 \pm 0.50$ & $12.67 \pm 0.20$ \\
\hline Lipids & $61.03 \pm 0.03$ & $56.12 \pm 0.06$ \\
\hline Total dietary fiber & $8.80 \pm 0.90$ & $10.05 \pm 0.75$ \\
\hline Carbohydrates ${ }^{\mathrm{b}}$ & 12.55 & 11.59 \\
\hline Total energy value (kcal) & 607.75 & 561.92 \\
\hline
\end{tabular}

${ }^{\mathrm{a}}$ Values expressed on a dry basis; ${ }^{\mathrm{b}}$ Obtained by difference.

Chart 1. Centesimal composition and mineral composition of baru cookies (mean \pm SD), nutritional value of the serving size ( $30 \mathrm{~g}$ ) and adequacy percentage of the serving size, in relation to the daily value.

\begin{tabular}{|c|c|c|c|c|c|}
\hline Nutrients & $\begin{array}{l}\text { Nutritional value of } \\
\text { baru cookie }(100 \mathrm{~g})^{\mathrm{a}}\end{array}$ & $\begin{array}{c}\text { Nutritional value of } \\
\text { baru cookie } \\
\left(\mathrm{g} .30 \mathrm{~g}^{-1}\right)\end{array}$ & $\begin{array}{c}\text { Adequacy percentage } \\
(\% \mathrm{DV})^{\mathrm{b}}\end{array}$ & $\begin{array}{c}\text { Nutritional value of } \\
\text { oat cookie } \\
\left(\mathrm{g} .30 \mathrm{~g}^{-1}\right)^{\mathrm{a}}\end{array}$ & $\begin{array}{c}\text { Adequacy percentage } \\
(\% \mathrm{DV})^{\mathrm{b}}\end{array}$ \\
\hline Moisture (g) & $7.80 \pm 0.18$ & 2.34 & - & 3.5 & - \\
\hline $\operatorname{Ash}(g)$ & $3.30 \pm 0.01$ & - & - & - & - \\
\hline Proteins (g) & $11.76 \pm 0.02$ & 3.53 & 5.65 & 3.43 & 5.48 \\
\hline Lipids (g) & $20.18 \pm 0.02$ & 6.05 & 12.1 & 5.35 & 10.7 \\
\hline Total dietary fiber (g) & $3.78 \pm 0.11$ & 1.13 & 4.52 & 1.05 & 4.20 \\
\hline Carbohydrates $(\mathrm{g})^{\mathrm{c}}$ & 60.98 & 18.29 & 5.63 & 25.10 & 7.72 \\
\hline Total energy value (kcal) & 457.46 & 137.24 & 6.86 & 158.11 & 7.90 \\
\hline \multicolumn{6}{|l|}{ Minerals } \\
\hline Calcium (mg) & $234.10 \pm 10.13$ & 70.23 & 7.02 & 57.86 & 5.79 \\
\hline Magnesium (mg) & $21.41 \pm 5.24$ & 6.42 & 1.61 & 4.07 & 1.02 \\
\hline Manganese (mg) & $13.32 \pm 2.41$ & 3.4 & 147.82 & 6.49 & 282.26 \\
\hline Phosphorus (mg) & $187.90 \pm 6.74$ & 59.37 & 8.48 & 44.52 & 6.36 \\
\hline Iron (mg) & $21.56 \pm 3.35$ & 6.47 & 80.87 & 3.15 & 39.41 \\
\hline Sodium (mg) & $55.80 \pm 3.65$ & 13.74 & 0.92 & 32.27 & 2.15 \\
\hline Potassium (mg) & $272.70 \pm 9.72$ & 81.81 & 1.74 & 79.05 & 1.68 \\
\hline Cuprum (mg) & $192.32 \pm 7.43$ & 57.70 & 6.41 & 64.01 & 7.11 \\
\hline Zinc (mg) & $10.85 \pm 9.94$ & 3.26 & 29.64 & 8.58 & 78.00 \\
\hline
\end{tabular}

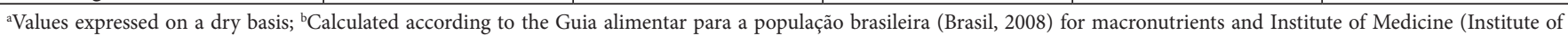
Medicine, 2011) for minerals; 'Obtained by difference.

the mineral analyses (Chart 1). The minerals chosen for analysis were those with higher nutritional relevance and described in the Nutritional Food Composition Table (Núcleo de Estudos e Pesquisas em Alimentação, 2011); calcium, magnesium, manganese, phosphorus, iron, sodium, potassium, cuprum and zinc.

The concentration of manganese in a portion of baru cookie (147.82\% RDA) was found to be above the recommendations recommended by IOM (2.05 mg/day) (2011). Baru cookies had higher concentrations of protein, dietary fiber and iron in a serving size, when compared to the oat cookies. The amount of protein found in the baru cookies was 1.03 times greater than that of the oat cookie and 1.7 times greater than other products of the same kind that are available on the market. Table 4 compares the serving size of the cookie developed in this study with the same quantity of similar cookies available on the market and marketed as healthy products and/or of functional appeal.

\section{Discussion}

The PDBF, obtained after cold oil extraction of the baru almond, was found to present a significant lipid concentration $(56.12 \% \pm 0.06)$. Siqueira et al. (2015), using a hydraulic press without heating and pressure control for baru oil extraction, obtained $12.97 \%$ lipids in the flour. This difference in extraction yield may be attributed to the conditions used, such as pressure and the time the almonds were in the press, as well as the initial quantity of nutrients in different cultivars. It would be of interest to combine solvent extraction and heating for the PDBF lipid content (up to 5\%) (Moretto \& Fett, 1986). However, the mechanical pressing extraction technique, commonly used for food and beverages, employs cold pressing and avoids the use of solvents and heating, thus generating a product with more preserved natural properties and being widely used for extracting oils with high contents of unsaturated fatty acids (Brennan et al., 1990). The flour obtained under the experimental conditions 
Table 4. Comparison of nutritional information of a serving size of baru cookie (30g) with cookies sold on the national market (30g).

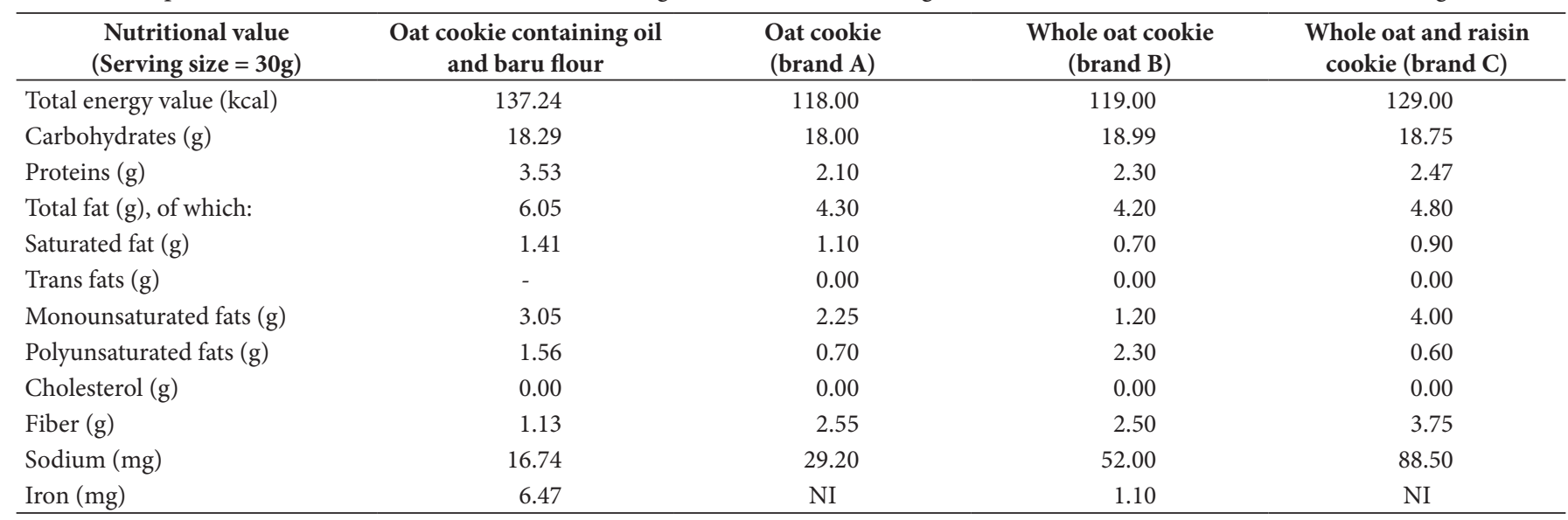

used in this study presented a high content of unsaturated fatty acids, especially of monounsaturated fatty acids (MUFA), proteins, iron and dietary fiber.

The oil extracted from the baru almond had a high concentration of unsaturated fatty acids (76.11\%), with $50.37 \%$ MUFA, of which $48.26 \% \pm 0.04$ was oleic acid (C18:1). On the other hand, the baru oil had a low concentration of saturated fatty acids (SFA) (23.36\%). These results are consistent with previous studies relating concentrations of $41.40 \%$ (Freitas \& Naves, 2010), 50.40\% (Takemoto et al., 2001) and 48.40\% (Fernandes, 2011) oleic acid in baru oil and low SFA in the baru almond (Freitas \& Naves, 2010; Bento et al., 2014.). As regards its fatty acid profile, the baru almond stands out as the almond with the highest concentration of MUFA consumed in Brazil (Freitas \& Naves, 2010) and may represent an approach for reducing the fractions of lipoproteins that augment serum cholesterol (LDL and VLDL).

Moreover, the fatty acid profile of the baru almond for $\omega-6: \omega-3$ was 20.48:1, while Freitas \& Naves (2010) observed a profile of 13.6:1 ( $\omega-6: \omega-3)$, therefore fulfilling the recommendations of the Institute of Medicine (Institute of Medicine, 2005), which recommends a fatty acid proportion of 5 to $10: 1(\omega-6: \omega-3)$ in a healthy diet. This above-the-recommended proportion of $\omega-6: \omega-3$ in the baru almond, in association with its bioactive compounds and high content of MUFA, may provide health benefits such as a reduction in hypercholesterolemia (Bento et al., 2014) and reduced lipid oxidation (Siqueira et al., 2012). Recently, Bento et al. (2014) observed that the consumption of $20 \mathrm{~g}$ baru almond reduced the serum concentrations of triglycerides, LDL-c and non-HDL-c in hypercholesterolemic individuals. The authors suggested that this positive effect may be attributed to the synergy between the fatty acid composition, fiber and bioactive compounds in the baru almond (Bento et al., 2014), such as phenolic acids.

The TP content of the baru cookie was 1.84 times higher than that of conventional cookies made with oats. Lemos et al. (2012) evaluated the TP content of roasted and unpeeled baru almonds and raw peeled baru almonds, reporting values of $111.3 \mathrm{mg}$ GAE/100g and $568.9 \mathrm{mg} \mathrm{GAE} / 100 \mathrm{~g}$, respectively. The heating of almonds in any processing step affects the distribution of the
TP between oil and TPDB, constituting the main cause of TP loss (Pineli et al., 2015a).

By comparing the centesimal composition of the original formulation developed with those of oat and WF, and without the addition of products derived from baru, there was an increase of $2.88 \%$ in protein concentration and $105.23 \%$ in iron. The increased nutritional quality of baru cookies may be due to the relevant nutritional quality of the residue generated by the baru oil almond extraction process (PDBF) and its high concentrations of antioxidants (Pineli et al., 2015a).

PDBF also contributed to the increase in dietary fiber concentration in the baru cookie and may consequently help reduce the consumer's glycemic index (GI). The baru cookie can be classified as a source of dietary fibers, because it contains approximately $3.78 \mathrm{~g}$ of dietary fiber per $100 \mathrm{~g}$ of product (Brasil, 2012). Previous studies have found similar results, where the addition of $8 \%$ PDBF (Soares et al., 2007), or the replacement of WF by $25 \%$ baru pulp in cookies (Alves et al., 2010), significantly increased the concentration of fibers in the products and presented a good sensory acceptance. Recently, Pineli et al. (2015b) developed a cake, replacing $100 \%$ of WF by PDBF, and obtained a product rich in fiber and with a high concentration of phenolic compounds, flavonoids and proteins.

The increased concentration of dietary fiber imparted by baru flour addition may be attributed to the baru almond shell present in this by-product (Pineli et al., 2015a). The presence of beta-glucans, resulting from the use of oats in cookies, is a relevant aspect of the product, as the consumption of these soluble fibers promotes health benefits, such as improved insulin resistance, dyslipidemia, hypertension and obesity (Khoury et al., 2012).

As observed in previous studies (Soares et al., 2007; Alves et al., 2010; Pineli et al., 2015a), cookies developed in this study also showed a high concentration of protein $(11.76 \%)$ and minerals, especially iron. Compared to leading market brands, baru cookies presented a 1.70-fold greater protein content. According to Freitas \& Naves (2010), the baru almond has an amino acid profile that fulfills the requirements of the majority of children's and adults' needs, and its use may also contribute to the recovery in health of individuals with nutritional complications, such as 
malnutrition or catabolic nutritional status, for example (Freitas \& Naves, 2010).

As such, the high protein content of the cookies developed in this study implies their potential for use as a food in school meals, with the aim of contributing to the essential amino acid supply at school. The significant iron content of the baru cookies ( $80.87 \%$ RDA) also deserves mention as these could reduce iron deficiency, the leading cause of most cases of anemia that can affect pre-school aged children. However, more studies need to be conducted to analyze the bioavailability of iron in these cookies and their benefits for the health of people who have a deficiency of this mineral. In addition, future studies should be carried out to analyze the content of other chemical compounds, such as phytosterols, selenium and tocopherols, which have antioxidant activities and may reduce the oxidative stress present in patients with obesity and dyslipidemia, for example.

\section{Conclusion}

The addition of baru oil and PDBF to bakery products, such as cookies, produces interesting foods from a nutritional point of view, as these cookies have high contents of MUFA, especially oleic fatty acid, dietary fiber, protein and iron. Thus, the use of baru flour in foods can contribute to the diversification of products with functional appeal as well as to the exploration of regional products, in order to promote the sustainable development of native areas. In contrast, the use of PDBF would reduce waste parts that are normally regarded as non-consumables, minimizing costs and waste generated to the environment.

\section{Acknowledgements}

We thank PIBIC/CNPq for financial support, the Institute of Food Technology (ITAL - Campinas, SP) for their help in the baru oil extraction, and the LOG (FEA - UNICAMP) for lipid analysis.

\section{References}

Alves, A. M., Mendonça, A. L., Caliari, M., \& Cardoso-Santiago, R. A. (2010). Avaliação química e física de componentes do baru (Dipteryx alata Vog.) para estudo da vida de prateleira. Pesquisa Agropecuária Tropical, 40(3), 266-273.

American Oil Chemists' Society - AOCS. (2009). Official methods and recommended practices of the American Oil Chemists' Society (5th ed.). Champaign: AOAC.

Bento, A. P. N., Cominetti, C., Simoes-Filho, A., \& Naves, M. M. (2014). Baru almond improves lipid profile in mildly hypercholesterolemic subjects: a randomized, controlled, crossover study. Nutrition, Metabolism and Cardiovascular Diseases, 24, 1330-1336.

Brasil. Agência Nacional de Vigilância Sanitária. (2012, Novembro 12). Resolução da Diretoria Colegiada $n^{\circ}$ 54, de 12 de Novembro de 2012. Dispõe sobre o Regulamento Técnico sobre informação nutricional complementar. Diário Oficial [da] República Federativa do Brasil, Brasília, DF.

Brasil. Ministério da Saúde. Secretaria de Atenção à Saúde. (2008). Guia alimentar para a população brasileira: promovendo a alimentação saudável (210 p.). Brasília: Ministério da Saúde.
Brennan, J. G., Butters, J. R., Cowell, N. D., \& Lilley, A. E. V. (1990). Food engineering operations. Linton Road: Elsevier Applied Science.

Fernandes, D. C. (2011). Efeito da Amêndoa de Baru, Amendoim e Castanha-do-Pará no perfil sérico e na peroxidação de lipídios em ratos com dieta hiperlipídica (Dissertação de mestrado). Programa de Pós-graduação em Ciência e Tecnologia de Alimentos, Universidade Federal de Goiás, Goiânia.

Freitas, J. B., \& Naves, M. M. V. (2010). Composição química de nozes e sementes comestíveis e sua relação com a nutrição e saúde. Revista Nutição, Campinas, 23(2), 269-279. http://dx.doi.org/10.1590/ S1415-52732010000200010.

Goldestein, J., \& Newbury, D. E. (1992). Scanning electron microscopy and x-ray microanalysis: a text for biologist, Materials Scientist and Geoloists (2nd ed., 840 p.). New York: Plennum Press.

Hartman, L., \& Lago, R. (1973). Rapid preparation of fatty acid methyl esters from lipids. Laboratory Practice, 22(6), 475-476. PMid:4727126.

Institute of Medicine - IOM. (2005). Dietary references intakes for energy, carbohydrate, fiber, fat, fatty acids, cholesterol, protein, and amino acids. Washington, DC: IOM.

Institute of Medicine - IOM. (2011). Dietary Reference Intakes (DRIs): estimated average requirements. Washington, DC: IOM.

Khoury, D. E., Cuda, C., Luhovyy, B. L., \& Anderson, G. H. (2012). Beta glucan: health benefits in obesity and metabolic syndrome. Journal of Nutrition and Metabolism, 2012, 851362. PMid:22187640. http:// dx.doi.org/10.1155/2012/851362.

Lemos, M. R. B., Siqueira, E. M. A., Arruda, S. F., \& Zambiazi, R. C. (2012). The effect of roasting on the phenolic compounds and antioxidant potential of baru nuts [Dipteryx alata Vog.]. Food Research International, Barking, 48(2), 592-597. http://dx.doi.org/10.1016/j. foodres.2012.05.027.

Lorenzi, H. (2002). Árvores brasileiras: manual de identificação e cultivo de plantas arbóreas nativas do Brasil (4. ed., 368 p.). São Paulo: Instituto Plantarum.

Moretto, E., \& Fett, R. (1986). Óleos e gorduras vegetais: processamento e análises. Florianópolis: UFSC.

Núcleo de Estudos e Pesquisas em Alimentação - NEPA. (2011). Tabela Brasileira de Composição de Alimentos - TACO (4. ed.). Campinas: NEPA.

Pedreiro, G. D. G. (2007) Torta gorda de girassol na alimentação de matrizes suínas em gestação e lactação (Dissertação de mestrado). Universidade Estadual de Londrina, Londrina.

Pineli, L. L. O., Carvalho, M. V., De-Aguiar, L. A., Oliveira, G. T., Celestino, S. M. C., Botelho, R. B. A., \& Chiarello, M. D. (2015a). Use of baru (Brazilian almond) waste from physical extraction of oil to produce flour and cookies. LWT - Food Science and Technology (Campinas), 60(1), 50-55.

Pineli, L. L. O., De-Aguiar, L. A., Oliveira, G. T., Botelho, R. B. A., Ibiapina, M. D. F. P., Lima, H. C., \& Costa, A. M. (2015b). Use of Baru (Brazilian Almond) waste from physical extraction of oil to produce gluten free cakes. Plant Foods for Human Nutrition (Dordrecht, Netherlands), 70(1), 50-55. PMid:25577329. http:// dx.doi.org/10.1007/s11130-014-0460-7.

Pio Corrêa, M. (1984). Dicionário das plantas úteis do Brasil (Vol. 2, 707 p.). Rio de Janeiro: Ministério da Agricultura.

Prosky, L., Asp, N., Furda, I., Devries, J. W., Schweizer, T. F., \& Harland, B. F. (1988). Determination of total dietary fiber in foods, food products and total diets: interlaboratorial study. Journal Association of Analitical Chemistry, 71(5):1017-23.

Rocha, L. S., \& Cardoso-Santiago, R. A. (2009). Implicações nutricionais e sensoriais da polpa e casca de baru (Dipteryx alata vog.) na elaboração 
de pães. Ciência e Tecnologia de Alimentos, 29(4), 820-825. http:// dx.doi.org/10.1590/S0101-20612009000400019.

Sano, S. M., Brito, M. A., \& Ribeiro, J. F. (2006). Baru. In R. F. Vieira, T. S. A. Costa, D. B. Silva, F. R. Ferreira \& S. M. Sano (Eds.), Frutas nativas da região Centro-Oeste do Brasil (1st ed., pp. 76-98). Brasília: EMBRAPA-CPAC.

Santos, G. G., Silva, M. R., Lacerda, D. B. C. L., Martins, D. M. O., \& Almeida, R. A. (2012). Aceitabilidade e qualidade físicoquímica de paçocas elaboradas com amêndoa de baru. Pesquisa Agropecuária Tropical, 42(2), 159-165. http://dx.doi.org/10.1590/ S1983-40632012000200003.

Santos, R. D., Gagliardi, A. C., Xavier, H. T., Magnoni, C. D., Cassani, R., Lottenberg, A. M., Arpadi Faludi, A., Geloneze, B., Scherr, C., Kovacs, C., Tomazzela, C., Carla, C., Barrera-Arellano, D., Cintra, D., Quintão, E., Nakandakare, E. R., Fonseca, F. A., Pimentel, I., Ernesto dos Santos, J., Bertolami, M. C., Rogero, M., Izar, M. C., Nakasato, M., Teixeira Damasceno, N. R., Maranhão, R., Cassani, R. S., Perim, R., \& Ramos, S. (2013). Diretriz sobre o consumo de Gorduras e Saúde Cardiovascular. Arquivos Brasileiros de Cardiologia, 100(1, Supl. 3), 1-40. PMid:23598539. http://dx.doi.org/10.5935/ abc.2013S003.

Singleton, V. L., \& Rossi, J. A. (1965). Colorimetry of total phenolics with phosphomolybdic-phosphotungstic acid reagents. American Journal of Enology and Viticulture, 16(3), 144-158.
Siqueira, E. M. A., Marin, A. M. F., Cunha, M. S. B., Fustinoni, A. M., Sant'ana, L. P., \& Arruda, S. F. (2012). Consumption of baru seeds [Dipteryx alata Vog.], a Brazilian savanna nut, prevents iron-induced oxidative stress in rats. Food Research International, 45(1), 427-433. http://dx.doi.org/10.1016/j.foodres.2011.11.005.

Siqueira, A. P. S., Pacheco, M. T. B., \& Veloso-Naves, M. M. (2015). Nutritional quality and bioactive compoundsof partially defatted baru almond flour. Food Science and Technology (Campinas), 35(1), 127-132. http://dx.doi.org/10.1590/1678-457X.6532.

Soares, M. S. S. Jr., Caliari, M., Tores, M. C. L., Vera, R., Teixeira, J. S., \& Alves, L. C. (2007). Qualidade de biscoitos formulados com diferentes teores de farinha de amêndoa de Baru (Dipteryx alata Vog.). Pesquisa Agropecuária Tropical, 37(1), 51-56.

Sousa, A. G. O., Fernandes, D. C., Alves, A. M., Freitas, J. B., \& Naves, M. M. V. (2011). Nutritional quality and protein value of exotic almonds and nut from the Brazilian Savanna compared to peanut. Food Research International, 44, 827-834.

Takemoto, E., Okada, I. A., Garbelotti, M. L., Tavares, M., \& AuedPimentel, S. (2001). Composição química da semente e do óleo de baru (Dipteryx alata Vog.) nativo do Município de Pirenópolis, Estado de Goiás. Revista do Instituto Adolfo Lutz, 60(2), 113-117. 